\title{
TEORETHICAL EVALUATION OF ANTHROPOGENIC RISKS IN TAZLAU RIVER BASIN
}

\author{
LUMINITA BIBIRE*1, MIHAELA-BEATRICE BARBIERU ${ }^{2}$, NARCIS BARSAN ${ }^{1}$, \\ ADRIAN STELIAN GHENADI ${ }^{1}$ \\ 1 "Vasile Alecsandri" University of Bacau, Calea Marasesti 157, Bacau, 600115, Romania \\ ${ }^{2}$ Zonal Training Centre for Civil Protection Bacau, Romania
}

\begin{abstract}
In the Tazlau Basin there was a really strong anthropogenic impact. Many areas have almost totally been deforested, the grazing and agriculture have extensively and irrational been practiced, underground reserves have been exploited, too etc. The expanding of settlements along the rivers and building of modern communication routes along beds favored the phenomena of flooding and destruction of hydraulic works. These all aspects led to frequent occurrence of risk events: erosions, landslides, degradation of the rivers beds, pollution of air, water, vegetation, soil, etc. The paper identifies anthropogenic risk factors from Tazlau Basin, and proposes analyzes of the consequences and the measures to avoid these ensuing consequences.
\end{abstract}

Keywords: anthropogenic risks, landscape management, allochthonous and autochthonous sources of pollution

\section{INTRODUCTION}

In the present, the Romanian legislation asks the local administrative institutions and economic operators to do the identification complex studies for assessment, monitoring and control regarding risk factors both for the geographical units and for administrative and territorial units.

The complexity and interdisciplinary of this kind of work is very high and often these institutions do not have human resources to do it. On the other hand, they have not financial resources to outsource this task to specialized companies (as it is in other EU countries) [1-3].

For these reasons, the existing studies are of poor quality and they contain information, which are insignificant and useless, so they do not ensure effective risk coverage $[4,5]$.

Tazlau Basin is located in Bacau county-Romania (Figure 1), and it is an area where anthropogenic impact was strong.

Starting the second half of the nineteenth century there is a real demographic explosion in this region and it was intensified the exploitation of wood, the industrial exploitation of coal, petroleum and other resources.

Areas with lower altitudes of 450-500 $\mathrm{m}$ have almost totally been deforested, extensive grazing and agriculture have extensively and irrational been practiced, reserves of oil and gas have been exploited etc.

\footnotetext{
*Corresponding author, e-mail: lbibire@ub.ro
}

(C) 2016 Alma Mater Publishing House 
Also, salt mining was developed in Tg. Ocna, then coal exploitation in the Comaneşti - Vermesti and the petroleum exploitation in Moinesti - Tescani - Tazlau was also developed. In terms of environmental quality risks, operating petroleum fields should be mentioned, especially the establishment of the petrochemical platform Tazlau from southern boundary of the Depression, respectively Onesti- Borzesti.

Also, during the recent decades large amounts of chemical fertilizers, pesticides and fungicides were used in agriculture and some great agro-zootechnical units had an intensive activity.

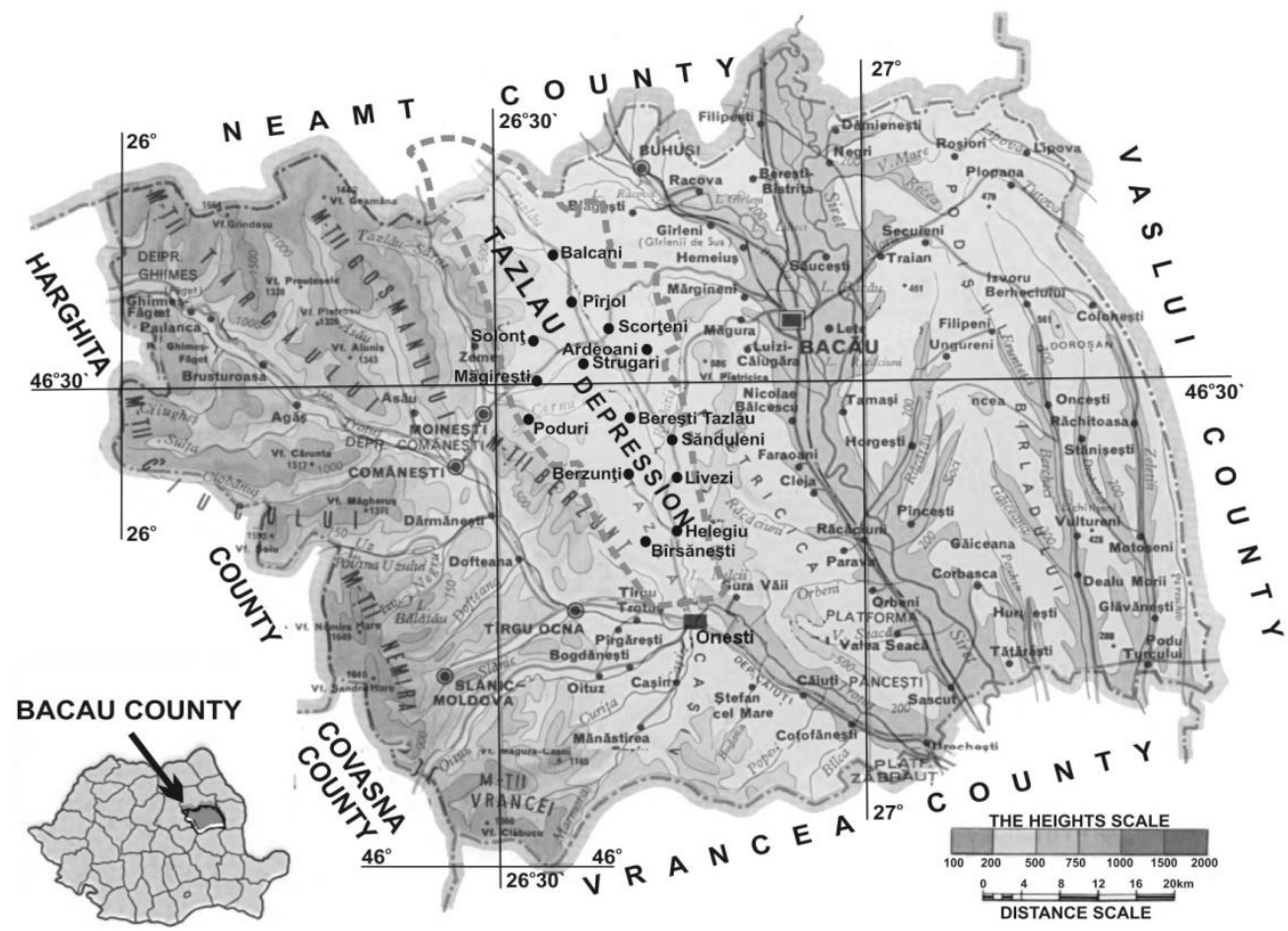

Fig. 1. Bacau County- Tazlau Basin.

Geomorphologic and geographical position, very favorable to biopedoclimatic feature of Tazlau Depression contributed at all these aspects.

All these aspects led to more frequent occurrence of risk events: areolar and rain erosions, landslides, degradation of the rivers beds, pollution of air, water (underground and surface), vegetation, soil etc., unwanted situations that are also presented by the specialty literature and for other areas of the world, too [6-9].

The expanding of settlements on rivers valleys and building of modern communication routes along rivers favored the phenomena of flooding and destruction of hydraulic works and art poorly designed or poorly located insufficiently designed or improper installed [5].

\section{EXPERIMENTAL SETUP}

2.1. The Impact of the Economic Development in the Area of Tazlau Basin, Romania, on the Environment Over time in Tazlau Basin, Romania several activity fields were developed. They had a benefic effect on the material aspects of people's life. On the other hand, like in other countries, they had negative consequences on environmental and thus on the people's life $[10,11]$.

\subsection{The Impact of Deforestation in the Area of Tazlau Basin, Romania, on the Environment}

From ancient times, the population exploited the existing wood from Tazlau Basin both for settlements expanding (1217 ha) and in favor of cultivated areas (24 $742 \mathrm{ha}$ ) or of grassland (26343 ha) or "release" of location for industrial units and ways of communication (1349 ha) (Figure 2). All these categories of land use have been 
expanded to the detriment of the forest. Forests, which are currently located on $27120 \mathrm{~km}^{2}(31.9 \%$ of the basin) retain few features of old forests and are uniformly distributed [5].

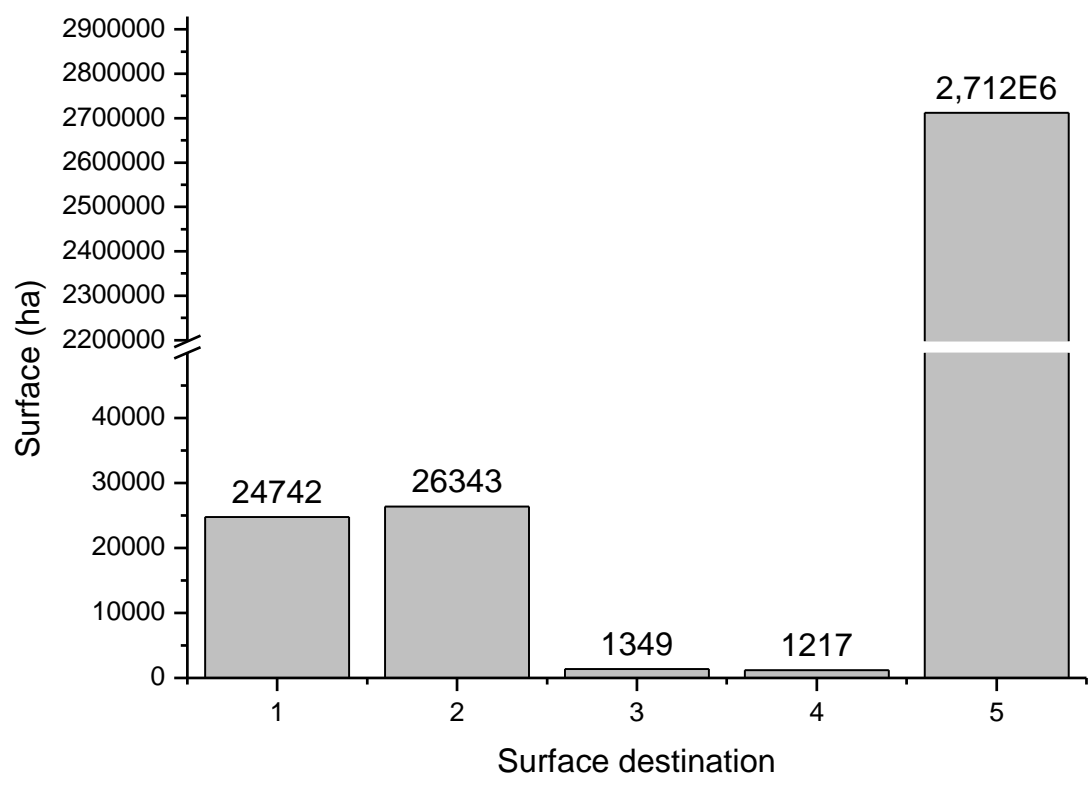

Fig. 2. The major surfaces and their destination in Tazlau Basin: 1 - cultivated areas; 2 - grassland; 3 - industrial units and ways of communication; 4 - settlements; 5 - forests.

In the central part of the depression, current coefficients of afforestation vary between $8.4 \%$ in Ardeoani area, $15.0 \%$ in Solont area, $15.4 \%$ in Parjol area while on the limitrophe areas of depression they have values above 40\% (60.6\% in Balcani area, 50.3\%, in Tazlau area, 46.7\% in Berzunţi area, 37.5\% Livezi area) (Figure 3).

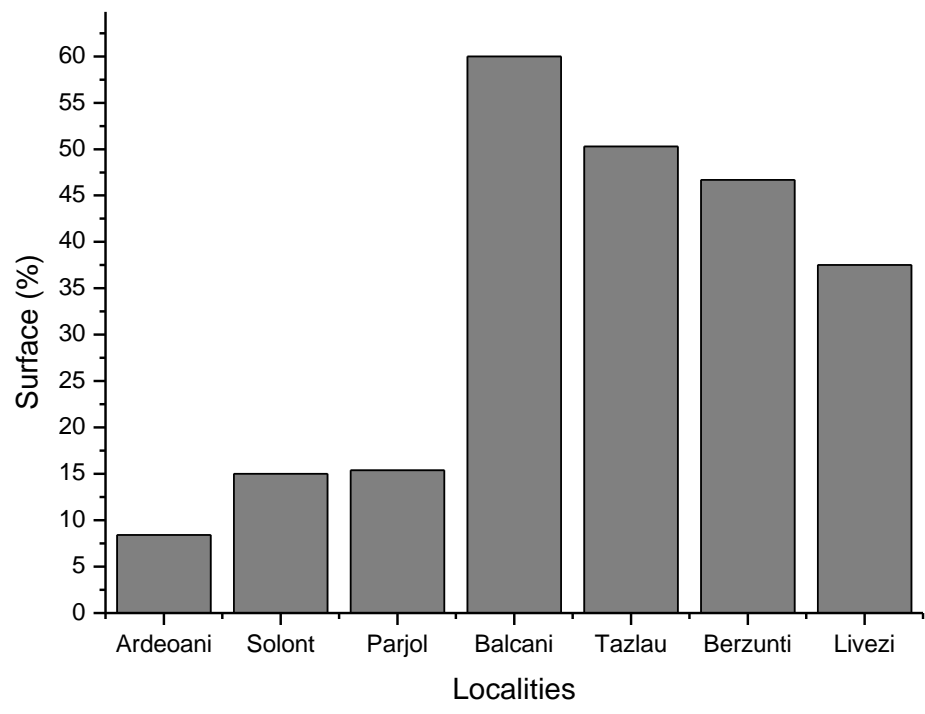

Fig. 3. The area occupied by forests in the case of some localities from Tazlau River Basin (as a percentage of the total area from the localities).

Deforestation is also linked to the identification of petroleum resources followed by their exploitation, which is done by performing drilling wells. When in forest areas petroleum resources are identified, a series of local 
deforestation of various sizes are imposed, which are added to other actions and they have the effect of forest fund reducing.

A part from exploitation locations have large areas, which are grubbed for achieving of the access roads or pipeline network.

On Tazlau Depression territory, in the Balcani, Parjol, Magireşti areas, petroleum resources were discovered on wooded land that imposed grubbing in order to exploitation.

Grubbed areas with sharp slopes are very vulnerable to the action of external agents, especially at torrential erosion. It can be said that deforestation, like in other parts of the world [12-15], even if it was made in favour of agricultural, pastoral and industrial activities, means an accelerated erosion, with clear connotations of major risks (flood, in depth and lateral erosion, landslides etc.) arising of land degradation [16].

\subsection{The Impact of Hydrotechnical and Hydroameliorated Works in the Area of Tazlau Basin, Romania, on the Environment}

Social - economic activities regarded as intended to increase the degree of civilization, and prosperity are not, in themselves, risk factors. Some side effects however may be harmful or even the catastrophic. But either out of ignorance or by conscious assumption of risks, people continue to carry out such activities, that exert increasing pressure on the environment and creates major imbalances in the natural, normal evolution of environment, as bibliographic studies show that happens other world regions, too [17, 18].

Works of earth around watercourses and around river basins are intended to ensure the water resources, protection against soil erosion and flood protection (accumulations, damming, regularizations and rectifications of beds) etc. In greater extent or lesser, all these works presents a potential risk. The most significant negative side effects are created by the accumulation lakes, the damming and the works to strengthen the riverbanks.

Currently, in the territory of Tazlau Basin, there are no significant accumulation lakes. Of course, for regularization of flow regime, it is necessary to continue building of accumulations, but they must be placed in appropriate conditions with additional insurances risks and the performance of additional work to combat erosion in its related hydrographical basin.

For protection against floods, the dikes play an important role, but their execution is not without risks. Dikes produce shock of flash floods waves, leading to excessive growth of erosion in river beds. There is also the danger that they to be overcome by levels of exceptional flash floods [19]. In this case, the damage and destruction is even greater. But the more so, to illusory shelter of the dykes, considered protected areas are densely populated and arranged from point of view of constructions. Along the river Tazlau are few dam areas, but such events have already occurred upstream of the bridge at Helegiu.

The consolidations and the protection of riverbanks involve fewer risks, but they exist. Most often, consolidations and protection of riverbanks can be eroded over the recessed points or are dug under them (Figure 4). When residues of such works are collapsed into river bed, they become an obstacle to the normal flow of water, causing additional growth of level and flood and lateral erosion on the great heights. Sometimes, even changes from this case, occurs in water courses

Risks consist in flooding, destruction of agricultural land and damages produced by destruction itself of such works which are quite expensive.

\subsection{The Impact of Industrial Activities in the Area of Tazlau Basin, Romania, on the Environment}

The main underground richness of Tazlau Basin is the petroleum, but in the S-E of it, on the Tg. Ocna - Onesti area, some influences of coal exploitation. The natural resources of the subsoil in Tazlau Basin and, in particular, the petroleum existence favored the development of exploitation industry and derived process industries.

Between the nineteenth and the twentieth century's on lands belonging to the following communes: Poduri, Magiresti, Solont, Balcani, Tazlau, drilling rigs were installed for geological prospecting. In these places, especially on hills near the western side of Berzunt Ridge, anthropogenic landforms remained as form of drilling platforms, large deposits of material resulted from drilling, access roads construction. 


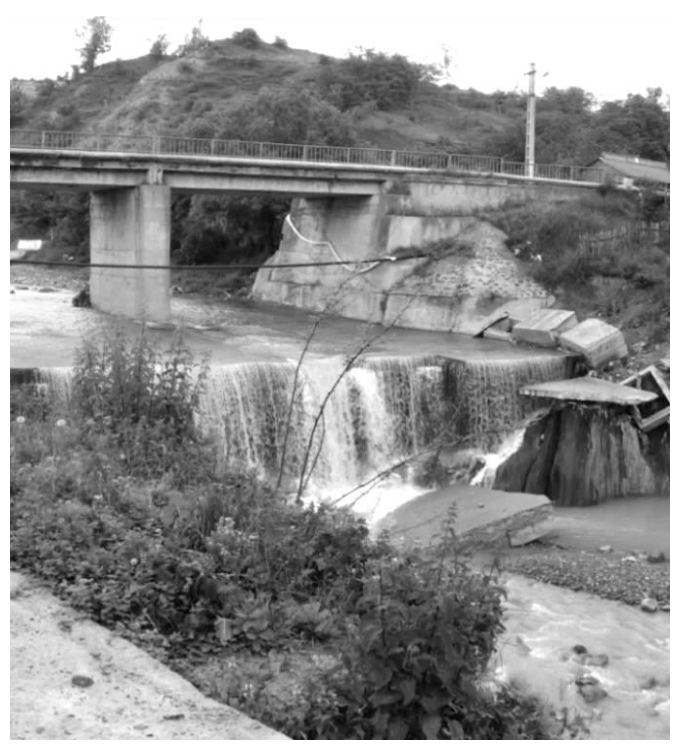

Fig. 4. Erosion accentuation, in depth, downstream of the concreted part of the bridge at Lucacesti (Tazlaul Sarat River).

Although, in a certain extent, reserves were reduced significantly, however there are numerous in exploitation or closed parks in operation, such as those from Tazlau, Balcani, Lucacesti, Moinesti Magireşti, Parjol, Ardeoani, Tescani, Targu Ocna etc. (Figure 5).

The work of extracting petroleum and its complicated transport network are elements of anthropic impact. Transposed as a risk factor, it is manifested by defined effects, among which the most important are imbalances produced in basement, micro relief changes and pollution of environment.

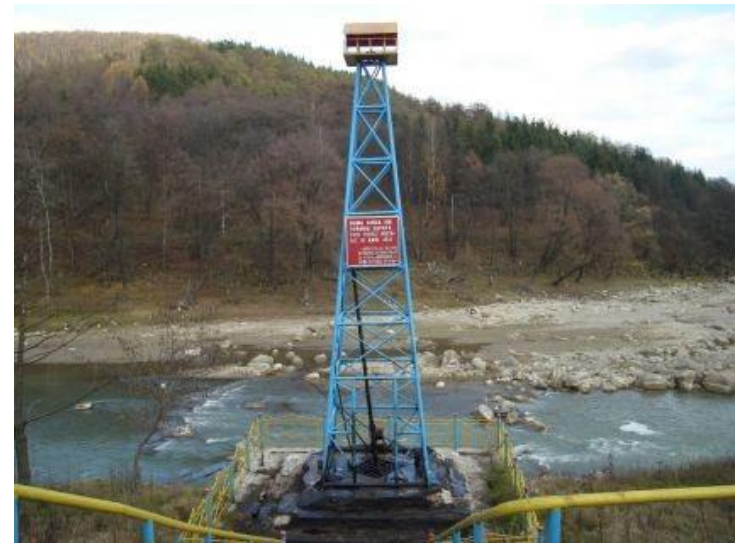

Fig. 5. Gas exploitation unit in Targu Ocna.

On the other hand, because of the overall economic development of the last century, on the territory of Tazlau Basin, many small economic societies with the industrial profile operated and still operate, and which are complex sources of environmental pollution.

Extraction and petroleum processing activities produce large amounts of waste, by a wide variety, affecting all parts of the environment. The most important environmental imbalances are produced on hydrosphere 
environment, and refer to the organoleptic and chemical changes encountered both at the surface water and groundwater, and at biospheric, pedosferic, atmospheric environmental, also.

Petroleum industry from the area, determined the appearance to a wide range of risks whose impact is manifested on many environmental components. Risks associated with the oil industry can be classified into the following groups:

- Social risks that involves displaced houses, restricting of settlements and of agricultural land, the occurrence of stress elements (explosions which could occur during the extraction or processing of petroleum, impure air, unstable land with highly erosion);

- Economic risks - the fluctuation of extracted material price, the occurrence of additional costs imposed by reasons (high costs for maintenance and for manufacture of various equipment necessary for petroleum extraction and processing, high cost of electricity, used water and so on);

- Risks environment, pollution phenomena at different scales on all environmental components, structural modifications in geographical landscape.

By petroleum exploiting it can be produced decompression of underground layers which include detachment phenomena and landslides. Examples can be considered the wells located in rough terrain: Tazlau, Balcani Parjol, Magireşti.

Also there is a continuous pollution of groundwater and surface water, of soil, of vegetation and of air.

Some accidental eruptions, inherent petroleum losses from surrounding of wells are major risk factors which can contribute to pollution of large areas of land. By exploiting and emanation of gas, the air pollution occurs and the wind can transmit the emissions at great distances. Also ground water, polluted watercourses and rainfall which escape on these areas contribute to transport of pollutant noxious.

The exploiting of petroleum is done in petroleum lands and includes a series of activities that have negative influences (sometimes serious) on environment.

Among these activities, it is mentioned:

- Deforestation for to install extraction wells, access roads, and pipeline networks;

- The exploitation of petroleum itself that can cause internal imbalances;

- Heavy road transport;

- $\quad$ Transport of petroleum (network).

\subsection{Impact of Transport Network from the Area of Tazlau Basin, Romania, on the Environment}

Through the construction of transport network (railway lines, roads, access roads) there are performed certain geographical landscape changes which, in principle, are not elements of risk.

Under certain conditions, however, these works may generate negative phenomena, sometimes with a high degree of risk (Figure 6). It's about heavy traffic roads built on land with potential for slip, undersized or poorly maintained bridges, high embankments, located across the width of the floodplain or along the basis of slopes, roads, forestry roads, or exploitation roads placed along the slopes and others.

In generally, for oil fields, heavy auto transport is used and, also old and heavily polluting equipment are in operation, too. Different situations request the access on the large slopes, on land with uncertain stability and this fact contributes greatly to the acceleration of torrential erosion and landslides processes.

Such situations can be observed in almost all areas where the isolated pipes or the groups of probes are located on land with slopes more pronounced, particularly Parjol and Magiresti.

Heavy road transport is a major source for pollution of air, soil, vegetation through the rainfall infiltration of water pollution.

In these areas, there are several routes of roads with big and heavy traffic (Bacau-Onesti and Bacau-Moinesti), which increases slip processes. 


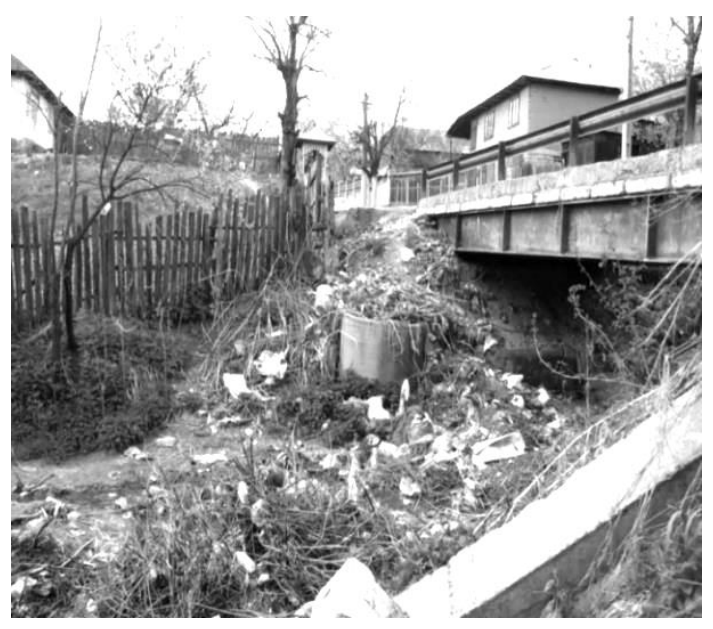

Fig. 6. Undimensioned and unkempt bridge over Helegiu creek, (Helegiu village).

\section{RESULTS AND DISCUSSION}

\subsection{Local Sources (Autochthonous) of Pollution and Sources Placed Outside of Tazlau Basin (Allochthonous Pollution)}

Although generally there is no significant pollution of Tazlau Basin, that represents a major degree of risk, in certain areas, such phenomena still exist. Such areas are affected by local sources of pollution (autochthonous pollution) or outside sources of Tazlau Basin (pollution allochthonous).

\subsection{Local Sources (Autochthonous) of Pollution}

Local sources of pollution are represented by industrial objectives in the area, the use (over time and present) of chemical fertilizers, herbicides and pesticides in agriculture, domestic wastewater and traffic auto.

a) Local industrial objectives. Outside the perimeters of petroleum exploitation, above mentioned, other local industrial units that produce pollution are located in the Lucacesti (Moinesti area), as well as in the most important localities, represented by slaughterhouses, butcher, woodworking shops, milk, and so on.

b) Agricultural pollution. This type of pollution is achieved mainly by organic substances, nitrates, nitrites, ammonium, phosphorus and special toxic substances (cyanides, aldehydes) from the use of fertilizers, herbicides and pesticides, and the manure from agro zootechnical complexes from manure spread on field. In recent years, agricultural pollution is into continuous decline, but noxious pollutants, especially nitrates and nitrites, are still maintained [20, 21]. Also, various agricultural associations or large farms still use chemical substances with polluting effect. In addition in region, there are still some agro zootechnical complexes of industrial type.

d) Local auto traffic. Auto circulation mainly affects the air quality and through dusts, soil, vegetation, the groundwater and surface waters. Road traffic emanates complex noxious, sometimes very dangerous: carbon monoxide, carbon dioxide, nitrogen dioxide, particulate matter, fumigants, unburned hydrocarbons, oxidation products (aldehydes, organic acids), halides lead, lead carbide, chloride ammonium etc. The most dangerous product emitted by exhaust gas is tetraethyl lead which acts as aerosols.

During recent years, auto traffic has greatly expanded, often without complying with strict environmental standards, so the pollution caused by them has increased significantly, but overall, environmental quality is better because of the economic recession. But, auto pollution presents some very dangerous components, and therefore it requires reduction measures.

An extremely serious effect is the car traffic on roads, which are not modernized. During the summer, the entrained dust from carriageway, mixed with noxious pollutants emitted by exhaust gas is deposited on the sides of roads, on surfaces large enough, and it is a significant risk factor for air, soil, vegetation and water. 
During recent years, air pollution in this area, do not exceed the limits, but as potential risk factor should be considered because it cannot be excluded absolutely the possibility of technological accidents.

Compared to limit $=1.00$, it is found that the coefficient values of air pollution are generally much smaller. This situation "relatively good" of air quality of Tazlau Basin does not mean that there are no problems in this area. The data presented above show that a degree of pollution exist and although there are not exceeded conventional limits allowed, it can still be a significant risk factor that must be given due attention, through cumulative effects from point of view of the noxious and time.

\subsection{Allochthonous Sources of Pollution}

Some sources of pollution affect the territory of Tazlau Depression, though they are located in outside the territory. This type of pollution relates, in particular, to air and water, which are environmental elements that represent the mobility.

a) Air pollution occurs through, transporting, by wind, of noxious from important economical objectives, situated near limits of Tazlau Basin. Atmospheric circulation that takes place along the depression, mainly from upstream but also from downstream on the Tazlau Sarat Valley, contributes to the noxious transport, and achieve of certain degree of local air pollution.

b) Water pollution occurs through transport of some noxious by watercourses from upstream to downstream. It is mainly the case of Tazlau, Tazlaul Sarat, and Trotuş Rivers which arrive in the Tazlau Basin, with a particular pollutant load: petroleum products, from Tazlaul Superior, pollutants from Darmaneşti and Comanesti mining areas (on Trotus), and pollutants due to industrial activities and household pollution from many existing objectives placed to upper of these river basins. Many of the pollutants are destroyed or neutralized towards downstream through natural capacity of watercourses self-cleaning, but it still arrives in depression. These concentrations often exceed critical limits. In the case of Tazlaul Sarat and Trotuş Rivers as major sources of pollution, household wastewater treatment and purification plants must be considered, which are insufficient dimensioned, particularly of cities Moineşti, Comanesti, Darmaneşti, Slanic Moldova and Tg. Ocna.

c) Pollution of soil and vegetation from allochthonous sources is less obvious but we do not refer on these phenomena. In the above context, Tazlau Basin is constituted in an area in which the complex phenomena of environmental pollution represent a permanent risk factor sometimes with connotations of great danger.

The main allochthonous sources, which affected and still pollute the environment (but now, in a small measure, due to the drastic reduction of industrial activities), (historical pollution), are:

- Refineries from Borzesti and Onesti, pollute the atmosphere with combustion products, steam and aerosols of petroleum products, smoke, dust, phenols, sulphur dioxide, etc., waters with phenols, hydrogen sulphide and other petroleum products. Soil also is contaminated with the same products as in the case of the air (through deposits) and of the water (through infiltration).

- Factory of synthetic rubber from Onesti, emanates into the atmosphere phenols, ammonia, sulphur dioxide, suspended particles, sediment particles, ammonia, phenols etc.

- Chemical Factory from Onesti, pollutes the air with chlorine, hydrochloric acid (aerosol), sulphur dioxide, ammonia, ammonium nitrate, cyanide, complex chemicals, detergents, pesticides, organic substances, etc.

- Factory of process equipment from Onesti, emanates, especially in the atmosphere, sulphur dioxide, metal powders, dusts, gas from foundry and smitheries and it pollutes less water and soil. The dust and the powder are deposited on soil and on vegetation.

- Other economic objectives of area Onesti - Borzesti represents major source of pollution, especially of the air.

The main sources of pollution from the mountain part of upper hydrographical basin of the Tazlau River are represented by exploitation oil parks from Tazlau village and surrounding of Tazlau village.

Pollution primarily refers to water resources, soil and vegetation, but pollution in this area had not a high degree. It was not realized a generalized chronic pollution, but there have been numerous accidental cases which had disastrous effects at local level (probe eruptions, fires, loss of petroleum from extraction and transport).

As in the case of Tazlaul Mare River in the upper hydrographic basin of the Tazlaul Sarat River, located in the mountain area, pollution sources are represented by petroleum exploitation from Bolatau, Zemes, Moinesti with 
similar effects on the environment. Here, the probes fields are more complex, and extraction points more numerous and, as result, the degree of pollution is greater.

On the banks of Tazlaul Sarat River it is located Moinesti City that had (and still has) complex industrial activities: primary processing of petroleum, mechanical companies for petroleum equipment and many smaller workshops. In this context, there are additional sources of pollution that affects the air (combustion products, vapors and aerosols of petroleum products, smoke, dust, phenols, sulphur dioxide), the water (phenol, hydrogen sulphide, aldehydes) the soil and the vegetation.

The pollutants from the air and especially from water enter on territory of Tazlau Basin, through atmospheric circulation or brought by Tazlaul Sarat River. In addition, for Moinesti City, household pollution must be mentioned which affects especially the water (organic sub-stances, phenols, detergents, complex chemical products, hydrogen sulphide).

Household pollution is accentuated by the fact that the many small workshops in the area, slaughterhouses, meat processing plants, dairies, have not their own treatment plant and they evacuate wastewater into municipal sewer network. Trotus River, which represents the southern boundary of Tazlau Basin between the following cities Tirgu Trotus and Onesti, come into area with a certain pollutant load: petroleum products from Asau area, Darmanesti, Larga, Dofteana, Cerdac Slanic, Tg. Ocna, Valcele. Pollutants from mining areas Darmaneşti and Comaneşti, industrial and household pollution from numerous sources of the cities Comanesti, Darmanesti, Tg. Ocna and from many wood processing units placed in the upstream of hydrographical basin.

\subsection{Proposal for pollutions reduction in Tazlau River Basin}

\subsubsection{Prevention of industrial pollution}

Pollution from industrial objectives can be predicted and analyzed in phases of design, construction, operation, and their closure and abandonment. In the design phase, at their location, the following aspects must be taken into account:

- The nature and sources of contamination generated by enterprises;

- The vulnerability of environment at specific pollution of the enterprise.

In order that impact of industrial objective on environmental to be minimal, the technical solutions offered by designer must be based on studies of meteorological, hydrological and soil, grouped in a complex environmental impact study. Depending on information offered by studies, a location outside the residential area will be search, taking into account the general and local direction of air masses, it will be done waterproofing area, it will be realized storage areas for materials and products, special equipment to prevent the pollution will be acquired and so on, in order not to affect the environment.

Depending on the specific activities, pollution prevention can take many forms:

- Equipping with devices for cleaning of water and neutralizing of pollutants (exhaust filters);

- Super elevation of chimney at units that generate large amounts of pollutants and smoke;

- The storage of potentially polluting liquids in secure containers resistant to damage;

- The storage of industrial waste on impermeable clay soils with groundwater at great depths, fitted with drain and neutralization systems of dangerous substances;

- Ensuring with collector basin of pollutants in case of breakdown and industrial accidents;

- Reduce of generation and deposition of gaseous effluents by applying clean technologies or by utilization of advanced equipment for depollution;

- Promote environmentally friendly productions, with clean technology application;

- Stimulation of enterprises in reducing the volume of waste, in processing and reuse them as secondary raw materials;

- Achieve of plant curtains for protection, around of industrial objectives.

The great industrial objectives belong to Onesti City. The concept, the design and the construction of these objectives, initially was well achieved, they were located far away from town, but over time, through expansion of inhabited territories, this area decreased, thus increasing pollution of the city. One example is that of the industrial platform placement of Onesti - Borzesti. 
The movement of noxious from this platform is made slightly to the north, because the position of these objectives is in the southeast of Onesti City, near the confluence of the Tazlau River with Trotus, which allows noxious to move along the Tazlau Valley for an atmospheric circulation from southeast.

\subsubsection{Prevention of agricultural pollution}

In recent years, agricultural pollution from Tazlau Basin is into a continuous decline, but pollutants noxious, especially nitrates and nitrites, still remain as residual sources. Prevention of pollution with chemical fertilizers is achieved by:

- Use of nitrogen fertilizer varieties without acidification potential, on moderate soils;

- Use of calcium improvers, on these soils, to combat the acidification.

Use of pesticides, herbicides and livestock manure in agriculture can have negative consequences on soil and groundwater.

Prevention of chemical and biological pollution is done by applying the following measures:

- Use only of pesticides and homologated phytosanitary products, in agriculture;

- $\quad$ Organic fertilizers can be applied only after an adequate treatment;

- Fertilizers application on soil is made only in accordance with the recommendations and instructions issued by authorized institutions.

\subsubsection{Prevention of household pollution}

In order to prevent household pollution, the following aspects are taken into consideration:

- Application of construction technologies with low environmental impact and using green building materials;

- Location of houses and outbuildings on safe land, with the possibility of removal of wastewater and residues only in public sewerage system, and when this is missing, through their own installations and facilities;

- Design and positioning of controlled landfills;

- Ecological education of the population.

\subsubsection{Prevention of pollution from transport}

Reduction of the complex noxious, due to the intense auto traffic is achieved by:

- Use of fuels that by burning doesn't release dangerous emissions (tetraethyl lead), such as unleaded gasoline and diesel fuel of high quality, to help reduce of pollution with heavy metals and of acid pollution;

- Use of internal combustion engines, properly adjusted and equipped with cleaning equipment;

- Modernization and maintenance of the roads, to prevent deposition of the dust mixed with noxious pollutants emitted by exhaust gas, on the lateral sides of the carriageway;

- Traffic prohibition by outdated cars or with combustion defects engines.

\section{CONCLUSIONS}

As it follows from the above presentation, sources of pollution from Tazlau Basin, are represented by industrial objectives, use of fertilizers, herbicides and pesticides from agriculture, domestic wastewater and auto traffic.

Local industrial objectives, centers of petroleum exploitation, slaughterhouses, meat processing units, wood working workshop, milk and so on, and other sources from outside of depression, for example Onesti - Borzesti, Moinesti, Comanesti, Darmanesti, Tg. Ocna, represent source of pollution for water resources (phenols, hydrogen sulphide, aldehydes), air (combustion products, vapors, and aerosols from petroleum products, smoke, dust, phenols, sulphur dioxide), soil (oil, sediments).

Agricultural pollution is mainly achieved by organic substances, nitrates, nitrites, ammonium, phosphorus, toxic substances (cyanide, aldehydes) from the use of fertilizers, herbicides, pesticides, manure from agricultural zootechnical complexes. The agricultural pollution affects water and soil.

Household pollution is generated by storage of waste on unsuitable places (rivers, soil etc.) and it affects mainly the waters from emissaries and to some extent the air. 
Auto traffic affects air, soil, vegetation, ground-water and surface water through sediments and complex noxious (carbon monoxide, nitrogen dioxide, unburned hydrocarbons lead halides etc.).

\section{REFERENCES}

[1] Matutinović, I., The prospects of transition to sustainability from the perspective of environmental values and behaviors in the EU 27 and globally in International, Journal of Sustainable Development and World, vol. 19, no. 6, 2012, p. 526-535.

[2] Mahmoudi, H., Renn, O., Vanclay, F., Hoffmann, V., Karami, E., A framework for combining social impact assessment and risk assessment, Environmental Impact Assessment Review, vol. 43, 2013, p. 1-8.

[3] Márton, P. 2012, A territorial understanding of sustainability in public development, Environmental Impact Assessment Review, vol. 32, no. 1, 2012, p. 61-73.

[4] Custură (Bărbieru), M.B., Studiul geografic al Depresiunii Tazlău cu privire specială asupra riscurilor naturale şi antropice, 2012, Ph.D. Thesis, Romanian Academy.

[5] Ceocea, C., Bibire, L., Ghenadi, A.S., The risk in management activity of a company for machine building, Applied mechanics and materials, vol. 656, p. 561-568.

[6] Iavazzo, P., Ducci, D., Adamo, P., Trifuoggi, M., Migliozzi, A., Boni, M., Impact of past mining activity on the quality of water and soil in the High Moulouya Valley (Morocco), Water air and soil pollution, vol. 223, no. 2,2012 , p. 573-589.

[7] Navarro-Ortega, A., Sabater, S., Barceló, D., Understanding effects of global change on water quantity and quali-ty in river basins - The SCARCE Project, Environmental science and pollution research, vol. 19, no. 4, 2012, p. 915-917.

[8] Zhang, J., Fu, M., Hassani, F.P., Zeng, H., Geng, Y., Zhongke, B., Land use-based landscape planning and restoration in mine closure areas, Environmental management, vol. 47, no. 5, 2011, p. 739-750

[9] Zornoza, R., Carmona, C.M., Acosta, J.A., Martínez-Martínez, S., Weiss, N., Faz, A., The effect of former min-ing activities on contamination dynamics in sediments, Surface water and vegetation in el avenque stream, SE Spain, Water air and soil pollution, vol. 223, no. 2, 2012, p. 519-532.

[10] Foronda-Roblesa, C., Galindo-Pérez-de-Azpillaga, L., Working with indicators: description of states of territorial adjustment for protected natural areas, International Journal of sustainable development \& world ecology, vol. 19, no. 4, 2012, p. 287-296.

[11] Vidal-Legaz, B., Martínez-Fernández, J., Sánchez Picón, A., Pugnaire, F.I., Trade-offs between maintenance of ecosystem services and socio-economic development in rural mountainous communities in southern Spain: A dy-namic simulation approach, Journal of Environmental Management, vol. 131, no. 2, 2013, p. 80-97.

[12] Dulala, H., Kalim, U.K., Chandan Sapkotac, S., Reducing emissions from deforestation and forest degradation (REDD) projects: lessons for future policy design and implementation, International journal of sustainable development \& world ecology, vol. 19, no. 2, 2012, p. 116-129.

[13] Howley, P., Examining farm forest owners' forest management in Ireland: The role of economic, lifestyle and multifunctional ownership objectives, Journal of environmental management, vol. 123, no. 15, 2013, p. $105-112$. [14] Kadioğullari, A.I., Assessing implications of land use and land cover changes in forest ecosystems of NE Turkey, Environmental monitoring and assessment, vol. 185, no. 3, 2013, p. 2095-2106.

[15] Peterson, K., Diss-Torrance, A., Motivation for compliance with environmental regulations related to forest health, Journal of environmental management, vol. 112, no. 1, 2012, p. 04-19.

[16] Vasilica, M., Capsa, D., Covaci, I., Nedeff, V., Bârsan, N., Panainte, M., A case study on heavy rainfall in the central-southern Moldavia Region, Romania, Environmental engineering and management journal, vol. 11 no. 12, 2012, p. 2151-2158.

[17] Abed-Elmdoust, A., Kerachian, R., River water quality management under incomplete information: application of an N-person iterated signaling game, Environmental monitoring and assessment, vol. 184, no. 10, 2012, p. 5875-5888.

[18] Jingwei, Z., Pingjia L., Ronghua, W., Yongli, C., Correlations between aesthetic preferences of river and landscape characters in Journal of environmental engineering and landscape management, vol. 21, no. 2, 2013, p. $123-132$

[19] Donaldson, A., Lane, S., Ward, N., Whatmore, S., Over flowing with issues: Following the political trajectories of flooding, Environment and planning, vol. 31, no. 4, 2013, p. 603-618.

[20] Islam, M.N., Jo, Y.T., Jung, S.K., Park, J.H., Evaluation of subcritical water extraction process for remediation of pesticide-contaminated, soil, water air and soil pollution, vol. 224, 2013, p. 16-52.

[21] Lebacq, T., Baret, V.P., Didier, S., Sustainability indicators for livestock farming, Agronomy for sustainable development, vol. 33, no. 2, 2013, p. 311-327. 